\title{
Cytoprotective and suicidal signaling in oxidative stress*
}

\author{
Luis A Videla \\ Molecular and Clinical Pharmacology Program, Institute of Biomedical Sciences, Faculty of Medicine, University of Chile, Santiago, Chile
}

\begin{abstract}
Oxidative stress is an imbalance between pro-oxidants and antioxidants in favor of the pro-oxidants, leading to different responses depending on the level of pro-oxidants achieved and the duration of exposure. In this article, we discuss the cytoprotective or suicidal signaling mechanisms associated with oxidative stress by addressing: (i) the development of an acute and mild pro-oxidant state by thyroid hormone administration eliciting the redox upregulation of the expression of proteins affording cell protection as a preconditioning strategy against ischemia-reperfusion liver injury; and (ii) the role of prolonged and severe oxidative stress and insulin resistance as determinant factors in the pathogenesis of non-alcoholic fatty liver disease associated with obesity.
\end{abstract}

Key terms: oxidative stress, thyroid hormone, liver preconditioning, obesity, insulin resistance, non-alcoholic fatty liver disease.

\section{INTRODUCTION}

Due to the aerobic nature of cellular metabolism, $\mathrm{O}_{2}$ reduction is a major event in biological systems. This process proceeds through one-electron transfer reactions, considering the electronic structure of $\mathrm{O}_{2}$ in the ground state with two unpaired electrons in the outer orbital. The result of one-electron reduction of $\mathrm{O}_{2}$ is the generation of reactive oxygen species (ROS) including free radicals, peroxides, and excited states (Videla and Fernández, 1988). The detoxication of ROS is a major prerequisite of aerobic life (Sies, 1986), which is accomplished via several enzymatic and nonenzymatic antioxidant mechanisms that are available in different cell compartments (Sies, 1986; Fernández and Videla, 1996). Secondary mechanisms restoring used cofactors and repairing altered biomolecules are also required, in addition to those triggering the expression of proteins damaged by ROS or needed to attain cell survival (Sies, 1986; Fernández and Videla, 1996; Dröge, 2002). These mechanisms need to be coupled to the intermediary metabolism for ATP, NADPH, and precursors supply, and depend on the dietary replenishment of essential components to maintain pro-oxidant reactions and cellular damage at a minimum level under basal conditions.

As proposed by Sies (1986), oxidative stress is a redox disequilibrium in which the pro-oxidant/antioxidant balance is shifted in favor of the pro-oxidants. At the cellular level, oxidative stress leads to a wide spectrum of responses, depending on the cell type, the level of ROS achieved, and the duration of the exposure (Dröge, 2002; Poli et al., 2004). The moderate increase in ROS and reactive nitrogen species (RNS) in a defined time window can elicit an imbalance capable of redox regulation, as found for $\mathrm{L}-3,3,5-$ triiodothyronine $\left(\mathrm{T}_{3}\right)$-induced oxidative stress (Varela et al., 2006), which may involve important signals regulating either protein function, via reversible oxidation or nitrosation of protein sulfhydryls, and/or gene expression, through modulation of specific kinases, phosphatases, and redoxsensitive transcription factors (Dröge, 2002; Poli et al., 2004). However, in the case of organs subjected to ischemiareperfusion (IR) (Romanque et al., 2005) or in obesity (Videla, 2008), large levels of ROS are attained, which may induce loss of cell viability and death. The relevance of oxidative stress on human pathology is manifold. Oxidative stress can trigger an irreversible situation in which severe oxidation of biomolecules by ROS cannot be overcome by antioxidant, repair, and biosynthetic pathways. This condition may also trigger dysregulation of signal transduction and gene expression, leading to cell death through necrotic and/or apoptotic mechanisms (Dröge, 2002). The limit between irreversible and reversible oxidative stress is not clear (Boveris et al., 2008), however, the latter form of redox imbalance involves stimulation of signal transduction mechanisms leading to beneficial effects, which may contribute to avoiding pathological events or help to recover from an already present pathological condition. In humans, determination of oxidative stress markers in blood and plasma usually reflect the production of ROS in the vascular space or oxidative damage occurring in target organs. Thus, antioxidant therapy may improve the health of patients with chronic pathologies or that are subjected to chemotherapy or radiotherapy; in these cases, assessment of systemic oxidative stress provides diagnostic and treatment control (Boveris et al., 2008).

In this review article, we address the cytoprotective or suicidal signaling mechanisms associated with oxidative stress by discussing (i) the implications of the redox regulation of $T_{3}$-induced gene expression as a preconditioning mechanism against IR liver injury; and (ii) the role of oxidative stress and insulin resistance as contributor factors in the pathogenesis of non-alcoholic fatty liver disease (NAFLD) in obese patients. 
OXIDATIVE STRESS AND CYTOPROTECTIVE SIGNALING: THYROID HORMONE LIVER PRECONDITIONING

\section{Thyroid hormone-induced liver oxidative stress}

In mammals, thyroid hormones exert major effects on cellular oxygen consumption $\left(\mathrm{QO}_{2}\right)$ and metabolic rates, leading to stimulation and maintenance of basal thermogenesis (Schwartz and Oppenheimer, 1978). This action of $\mathrm{T}_{3}$ is carried out via thyroid hormone receptors expressed in almost all tissues, which are recognized by specific thyroid hormone response elements in DNA, leading to ligand-dependent upregulation of the expression of respiratory, metabolic, and uncoupling protein genes (Fig. 1A) (Videla et al., 2007). In addition to the above classical genomic model of $\mathrm{T}_{3}$-dependent calorigenesis, non-genomic mechanisms may also contribute to increasing cellular $\mathrm{QO}_{2}$, with the consequent enhancement of the mitochondrial capacity for oxidative phosphorylation and ROS generation (Fernández and Videla, 1993). $\mathrm{T}_{3}$-induced ROS production also involves (i) higher activities of microsomal NADPHcytochrome P450 reductase (Ram and Waxman, 1992) and NADPH oxidase (Fernández et al., 1985), which is related to the induction of the highly pro-oxidant cytochrome P4502E1 isoform by $\mathrm{T}_{3}$ (Fernández et al., 2003); (ii) $\mathrm{O}_{2} \cdot-/ \mathrm{H}_{2} \mathrm{O}_{2}$ generation by xanthine oxidase (Huh et al., 1998) or coupled to enhanced fatty acid $\beta$-oxidation due to liver peroxisomal proliferation (Fernández and Videla, 1993); and (iii) Kupffercell activation with increased respiratory burst activity due to NADPH oxidase (Tapia et al., 1997).

Liver depletion of antioxidant defenses is a major consequence of $\mathrm{T}_{3}$-induced ROS generation, leading to enhancement in the oxidative stress status of the liver (Fig. 1A) (Varela et al., 2006; Venditti and Di Meo, 2006; Videla et al., 2007). This pro-oxidant state achieved in the liver by $\mathrm{T}_{3}$ induced calorigenesis can be considered as a mild redox alteration, as suggested by the lack of occurrence of morphological changes in liver parenchyma, except for the significant hyperplasia and hypertrophy of Kupffer cells, the resident macrophages of the liver (Tapia et al., 1997) playing a central role in the homeostatic response to liver injury (Tsukamoto, 2002).

$T_{3}$-induced Kupffer cell-dependent upregulation of cytokine expression and hepatocyte proteins related to cytoprotection

Kupffer cell hyperplasia is a major finding after in vivo $\mathrm{T}_{3}$ administration, an effect that may involve the expansion of Kupffer cell precursors by means of circulating monocyte recruitment, the differentiation of pre-existing local Kupffer cell precursors into mature liver macrophages, or both (Gomes et al., 2004). Consequently, enhancement in Kupffer cell function is achieved as shown by the significant increases in the rate of carbon phagocytosis and the associated carbon-induced $\mathrm{O}_{2}$ uptake representing the respiratory burst activity of Kupffer cells. This process is largely dependent on the activity of the ROS-generator NADPH oxidase and abolished by pretreatment with the Kupffer cell inactivator gadolinium chloride $\left(\mathrm{GdCl}_{3}\right)$ (Fig. 1A) (Tapia et al., 1997). Under these conditions, significant increases in the hepatic DNA binding of the transcription factors NF-кB (Tapia et al., 2003), STAT3 (Tapia et al., 2006), and AP-1 (Fernández et al., 2007a) (Fig.1A) are observed. Activation of these transcription factors by $\mathrm{T}_{3}$ administration is suppressed by the in vivo pretreatment with $\mathrm{GdCl}_{3}$ or antioxidants prior to hormone treatment (Tapia et al., 2003; 2006), thus supporting the view that $T_{3}$ induces the redox activation of hepatic NF-кB, STAT3, and AP-1 by actions primarily exerted at the Kupffer cell level (Fig. 1A). $\mathrm{T}_{3}$ administration involving significant NF- $\mathrm{B}$ and $\mathrm{AP}-1$ activation induced mRNA expression of the NF-кB/AP-1responsive genes for TNF- $\alpha$, with increased serum levels of the cytokine (Fernández et al., 2002; Tapia et al., 2003). $T_{3}$ also elicited an increase in the serum levels of IL-6 (Tapia et al., 2006) and in the hepatic mRNA expression and serum levels of IL-1 (Tapia et al., 2003). In addition to NF-אB and AP-1 activation, the enhancement in STAT3 DNA binding by $\mathrm{T}_{3}$ administration (Tapia et al., 2006) may be associated with the proliferation of macrophage precursors and their differentiation into Kupffer cells (Gomes et al., 2004), considering the central role of STAT3 in gp130-mediated cell growth, differentiation, and survival (Hirano et al., 2000).

The effects of cytokines released from Kupffer cells are exerted through their interaction with specific surface receptors in target cells within the liver to mediate signaling from cell membrane to the nucleus (Tsukamoto, 2002). In agreement with the above view, the transient TNF- $\alpha$ response elicited by $\mathrm{T}_{3}$ administration correlates with the substantial increase in liver I $\mathrm{I} B-\alpha$ phosphorylation (Fernández et al., 2005a; 2005b), evidencing the activation of the IKK complex that activates NF-אB (Gloire et al., 2006). $\mathrm{T}_{3^{-}}$ induced TNF- $\alpha$ response, liver IKK phosphorylation, and NF- $\kappa \mathrm{B}$ activation are abolished by pretreatment with either a-tocopherol or $\mathrm{GdCl}_{3}$, supporting the role of ROS production and Kupffer-cell activation in $\mathrm{T}_{3}$-dependent signaling (Fernández et al., 2005a; 2005b). This is evidenced by upregulation of the NF- $\kappa B$-responsive genes encoding for the hepatoprotective proteins inducible NOS (iNOS) (Fernández et al., 2005a), manganese superoxide dismutase (MnSOD), and the anti-apoptotic protein Bcl-2 (Fernández et al., 2005b) (Fig. 1A).

$\mathrm{T}_{3}$ administration also upregulated the acute-phase response (APR) of the liver and hepatocyte proliferation. The APR is a major pathophysiologic reaction, in which normal homeostatic mechanisms are replaced by new set points contributing to defensive or adaptive capabilities against inflammation and oxidative stress (Ramadori and Christ, 1999). In fact, $T_{3}$ induced the Kupffer-cell-dependent release of IL-6 and activation of hepatic STAT3 controlling both type I (haptoglobin) and type II ( $\beta$-fibrinogen) acute-phase protein (APP) genes (Tapia et al., 2006), a response that may be contributed to by upregulation of the TNF- $\alpha / \mathrm{IKK} / \mathrm{NF}-\kappa \mathrm{B}$ pathway (Fernández et al., 2005a; 2005b) controlling type I APP genes (Agrawal et al., 2003). Furthermore, the in vivo effects of $\mathrm{T}_{3}$ as a primary hepatic mitogen leading to hepatocyte proliferation in intact liver are well established (Fig. 1A) (Fernández et al., 2007a), a process involving a large number of genes that requires the concurrence of cytokine, growth factor, and metabolic networks (Fausto et al., 2006). Resting hepatocytes in the G0 phase of the cell cycle need to be primed by TNF- $\alpha$ and IL- 6 before they can respond to growth factors, with the concomitant activation of NF-кB, STAT3, AP-1, and E/EBPb, to enter the G1 phase and initiate cell cycle progression. $\mathrm{T}_{3}$ administration was 
associated with increased liver cyclin-dependent kinase 2 expression and hepatocyte proliferation, as evidenced by the enhancement in Ki-67, a nuclear cell proliferation-associated protein expressed in all active parts of the cell cycle, and in the proliferating cell nuclear antigen (PCNA) (Fernández et al., 2007a).

Collectively, the data discussed indicate that $\mathrm{T}_{3}$ triggers cytoprotection in the liver through redox- and Kupffer cell- dependent signaling mechanisms, leading to (i) antioxidant responses (iNOS, MnSOD); (ii) anti-apoptosis (Bcl-2); (iii) immune, transport, and antioxidant (haptoglobin, ceruloplasmin, ferritin) functions fulfilled by APR induction; and (iv) hepatocyte proliferation (Fig. 1A) being the associated metabolic demands met by acceleration of energy metabolism due to $\mathrm{T}_{3}$-induced calorigenesis (Varela et al., 2006; Videla et al., 2007).

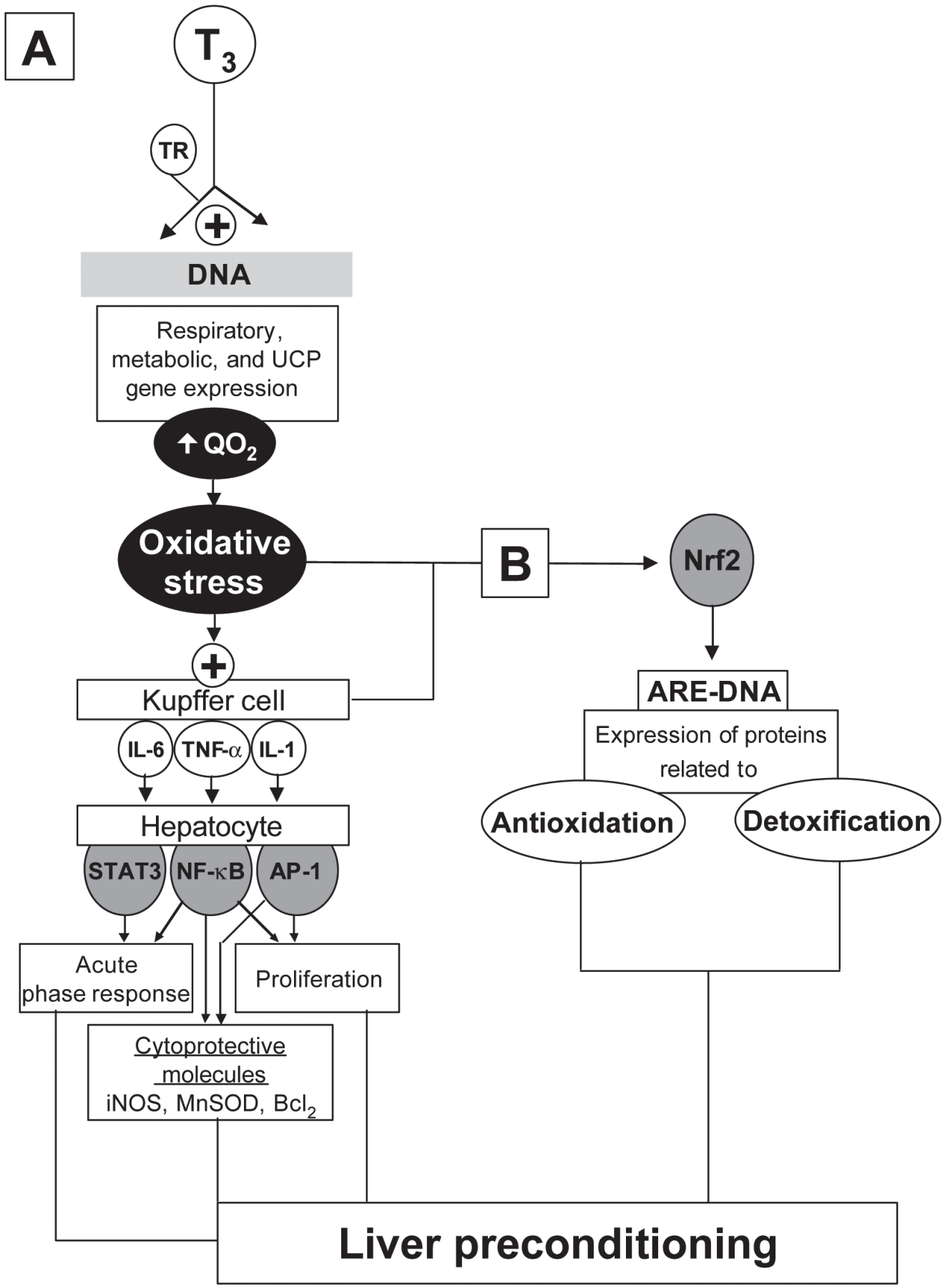

Figure 1: Oxidative stress signaling in thyroid hormone $\left(T_{3}\right)$ liver preconditioning as mediated by redox-sensitive transcriptional factors NF- $\mathrm{K}$, AP-1, and STAT3 (A) or Nrf2 (B). Abbreviations: AP-1, activating protein 1; ARE, antioxidant responsive element; GdCl 3 , gadolinium chloride; IL, interleukin; iNOS, inducible nitric oxide synthase; MnSOD, manganese superoxide dismutase; NF- $\mathrm{B}$, nuclear factor- $\mathrm{kB}$; Nrf2, nuclear factor-erythroid 2-related factor 2; $\mathrm{QO}_{2}$, rate of oxygen consumption; TNF- $\alpha$, tumor necrosis factor- $\alpha$; STAT3, signal transducer and activator of transcription 3; TR, thyroid hormone receptor; UCP, uncoupling protein. 
Thyroid hormone-induced liver preconditioning

In general terms, IR injury refers to tissue damage produced by blood perfusion to the previously ischemic organ, which in the liver is associated with the clinical settings of hepatic resection, transplantation, low-blood pressure states, and abdominal surgery requiring hepatic vascular occlusion (Romanque et al., 2005; Casillas-Ramírez et al., 2006). IR liver injury assessed in a model involving 1 hour of partial ischemia induced by vascular clamping followed by reperfusion for $20 \mathrm{~h}$ elicited substantial liver damage, concomitantly with (i) a drastic increase in the oxidative stress status of the liver and TNF- $\alpha$ response; (ii) loss in the DNA binding of NF- $\mathrm{B}$ and STAT3 implying loss of cytoprotective potential; and (iii) enhancement in the hepatic AP-1 DNA binding activity, which may constitute a major determinant of hepatotoxicity under conditions of reduced NF- $\kappa \mathrm{B}$ activation and TNF- $\alpha$ response (Fernández et al., $2007 b ; 2008)$. These changes were normalized by $\mathrm{T}_{3}$ treatment given $48 \mathrm{~h}$ before the IR protocol, a preconditioning effect that was sensitive to the antioxidant $\mathrm{N}$-acetylcysteine given prior to $\mathrm{T}_{3}$ (Fernández et al., 2008), with enhanced hepatocyte proliferation compensating for liver cells lost due to IR-induced hepatocellular necrosis (Fernández et al., 2007a).

In conclusion, redox regulation of gene transcription induced by $\mathrm{T}_{3}$ involves antioxidant-sensitive NF-кB, AP-1, and STAT3 activation and upregulation of the expression of cytoprotective proteins affording liver preconditioning (Fig. 1A) (Fernández and Videla, 2009). $T_{3}$ liver preconditioning may also involve the activation of the Nrf2-Keap1 defense pathway up-regulating antioxidant proteins and phase-2 detoxifying enzymes (Fig. 1B) (Kobayashi and Yamamoto, 2005), which is currently under study in our laboratory.

\section{OXIDATIVE STRESS AND SUICIDAL SIGNALING: NON- ALCOHOLIC FATTY LIVER DISEASE (NAFLD) ASSOCIATED WITH OBESITY}

Oxidative stress and insulin resistance as pathogenic factors in steatosis in obese NAFLD patients

NAFLD includes simple triacylglycerol (TAG) accumulation in hepatocytes (hepatic steatosis) or steatosis with inflammation, fibrosis, and cirrhosis (non-alcoholic steatohepatitis, NASH), with oxidative stress, insulin resistance, and nutritional factors playing major contributory roles (Angulo, 2002; Videla et al., 2004a). Fatty acids (FAs) are the major oxidative fuel in the liver under most circumstances, however, carbohydrate and lipid affluence induce significant changes in hepatic intermediary metabolism. In fact, high glucose and insulin levels stimulate FA synthesis from glucose and inhibit FA $\beta$-oxidation, redirecting FAs towards the formation of TAG (Videla, 2008). Upon consumption of calorie-enriched diets, FAs in excess are likely converted to TAGs and stored as lipid droplets within hepatocytes due to limitations in VLDL synthesis and export. Since non-adipose tissue has limited capacity for TAG storage, the lipids in excess that accumulate under conditions of over-nutrition determine high intracellular levels of saturated FAs, which can induce cell dysfunction and/or cell death, a phenomenon known as lipotoxicity
(Aronis et al., 2005). Consequently, higher rates of FA oxidation and ROS generation are achieved, which might explain the increases in the oxidative stress-related parameters and antioxidant depletion found in the liver of obese NAFLD patients with steatosis (Fig. 2) (Videla et al., 2004b; Videla, 2008). Prolonged oxidative stress might, in turn, favour: (i) liver $n$-3 LCPUFA depletion, which may be compounded by dietary imbalance and defective desaturation activity (Araya et al., 2004; Elizondo et al., 2008); and (ii) insulin resistance, in association with the redox activation of multiple stress-sensitive serine/threonine kinases that alters insulin signaling (Fig. 2) (Evans et al., 2005), a phenomenon is a membrane-mediated process that might be also compromised by $n$-3 LCPUFA depletion due to loss of membrane polyunsaturation. Both IR and liver $n-3$ LCPUFA depletion can determine hepatic steatosis by different mechanisms, namely, (i) insulin resistancedependent higher peripheral mobilization of FA and glycerol to the liver; and (ii) n-3 LCPUFA depletion-induced changes in the DNA binding activity of the peroxisome proliferatoractivated receptor-a (PPAR-a)/sterol regulatory element binding protein-1c (SREBP-1c) couple, determining a metabolic imbalance between FA oxidation and lipogenesis in favor of the latter (Fig. 2). This contention is based on the findings that $n-3$ LCPUFA are signaling biomolecules regulating hepatic lipid metabolism through (i) downregulation of the expression of SREBP-1c and its processing, with inhibition of the transcription of lipogenic and glycolytic genes; and (ii) upregulation of the expression of genes encoding enzymes of FA oxidation, acting as ligand of PPAR-a (Clarke, 2004).

Hepatic oxidative stress enhancement and progression from steatosis to steatohepatitis

In steatohepatitis, the alterations in oxidative stress indexes found in steatosis are observed concomitantly with (i) low catalase activity (Videla et al., 2004b); (ii) high immunohistochemical reactivity to 8hydroxydeoxyguanosine and 4-hydroxy-2-nonenal as markers of oxidative DNA damage and lipid peroxidation, respectively (Seki et al., 2002); (iii) a further increment in 3nitrotyrosine immunoreactivity and in the production of $\mathrm{O}_{2}$ and malondialdehyde by Kupffer cells; (iv) induction of inducible nitric oxide synthase; and (v) upregulation of cytochrome P450 2E1 (CYP2E1) as evidenced by the higher protein expression of CYP2E1 and in vivo chlorzoxazone hydroxylation, an indicator of CYP2E1 activity (Fig. 2) (Videla, 2008).

Exacerbation of the oxidative stress status of the liver in steatohepatitis compared to steatosis seems to involve several mechanisms (Fig. 2). Upregulation of liver CYP2E1 (Videla et al., 2004b; Orellana et al., 2006) is of particular importance in the pathogenesis of NASH due to its large capacity for ROS generation with the consequent lipid peroxidation response (Caro and Cederbaum, 2004). Hepatic mitochondrial dysfunction is an alternate contributory factor to the genesis of lesions in steatohepatitis, considering the lower levels of mitochondrial DNA and decreased expression of mitochondrial DNA-encoded proteins, with reduced activity of respiratory complexes I, III, and IV, and ATP synthase complex $\mathrm{V}$ and enhanced ROS generation 
(Angulo, 2002). In addition, mixed inflammatory-cell infiltration is a characteristic feature of NASH including mononuclear cells, polymorphonuclear cells, or both (Angulo, 2002), which may represent an additional mechanism of ROS generation due to the expression and activation of NADPH oxidase (NOX2), an enzyme producing large amounts of ROS (Babior, 2004). NOX2 is also expressed in Kupffer cells, which in patients with steatohepatitis produce ROS at rates that are 20-fold higher than normal, with a substantial increase in Kupffer cell-dependent lipid peroxidation in steatohepatitis patients (Malaguarnera et al., 2006). Under these conditions, the oxidative stress status of the liver achieved in steatohepatitis might promote hepatocellular damage by inducing (i) severe oxidative alteration of biomolecules with loss of their functions and impairment of cell viability; and (ii) prolonged activation of redox-sensitive transcription factor such as NF- $\mathrm{KB}$ and AP-1, with consequent upregulation of the expression of proinflammatory mediators at the Kupffer cell level (Fig. 2) (Videla et al., 2009).

Collectively, the discussed evidence supports the view of a functional interdependence between oxidative stress and insulin resistance (Fig. 2). This proposal might involve (i) the onset of ROS production due to lipotoxicity and the consequent development of insulin resistance in steatosis; and (ii) a further enhancement in ROS generation due to CYP2E1 induction, mitochondrial dysfunction, and phagocyte NOX2 activity characterizing steatohepatitis. Dysregulation of pro-inflammatory cytokine, adipokine, and chemokine signaling in NAFLD may reinforce the initial mechanisms of ROS production and IR, representing key factors in the progression from stable steatosis to steatohepatitis, in the setting of oxidative stress-mediated hepatocyte sensitization (Videla et al., 2004a; Videla et al, 2006). In this context, antioxidants can act as insulin sensitizers by lowering ROS levels, a condition that might abrogate free-radical-mediated activation of signaling serine/threonine kinases and damage to biomolecules, as shown in cell-culture studies (Houstis et al., 2006). However, these findings remain to be confirmed in obese NAFLD patients.

\section{CONCLUDING REMARKS}

The development of extreme levels of oxidative stress in the liver determines opposite cellular responses, depending on the period of exposure to ROS. Following $\mathrm{T}_{3}$ administration, induction of a mild pro-oxidant state within a time window of $48 \mathrm{~h}$ triggers liver preconditioning (Fernández et al., 2007b). This preconditioning strategy has clinical potential,

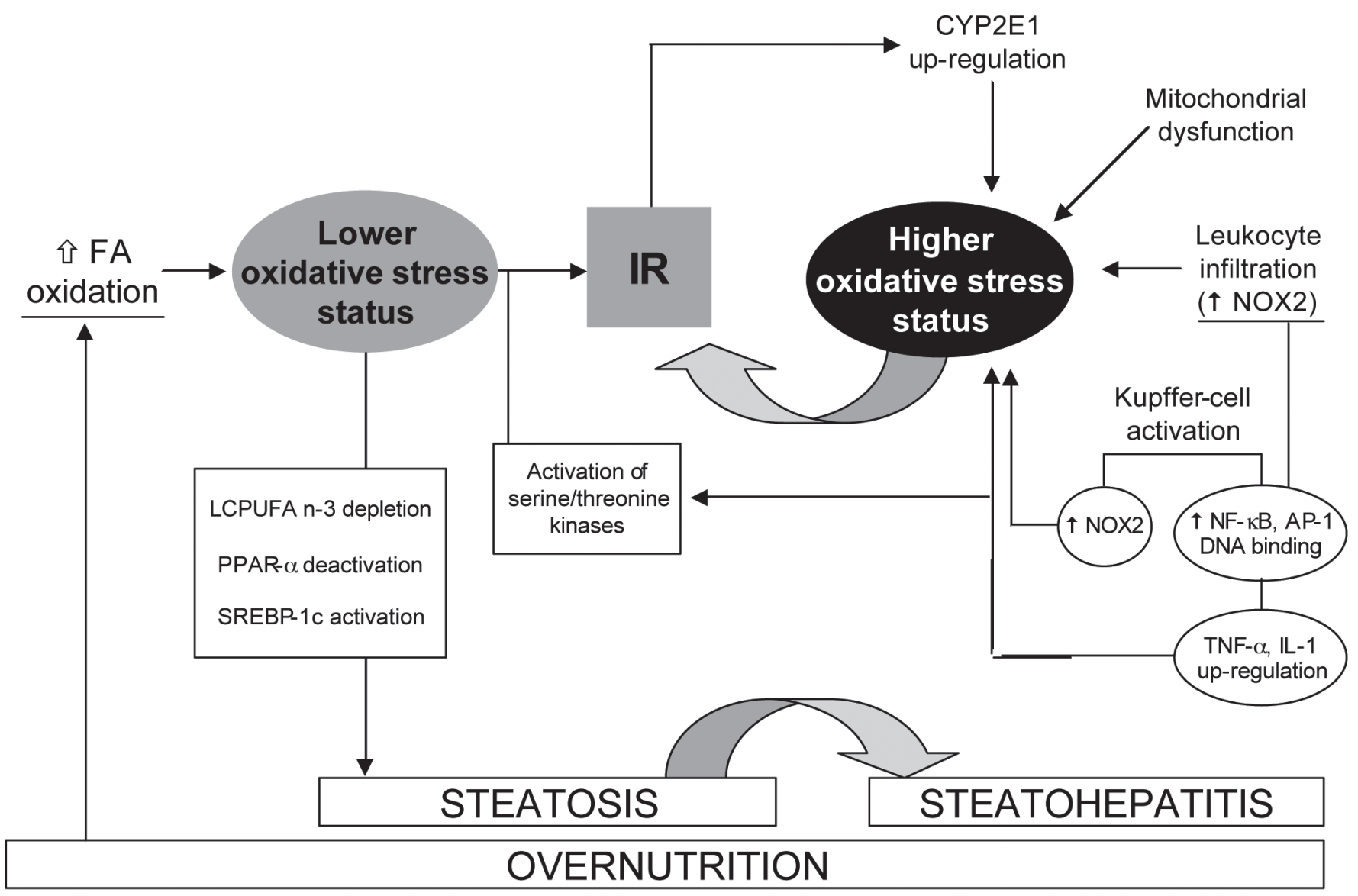

Figure 2: Interrelationships between the level of oxidative stress and insulin resistance achieved leading to hepatic steatosis and its progression to steatohepatitis associated with over-nutrition. Abbreviations: AP-1, activating protein 1; CYP2E 1, ethanol inducible form of cytochrome P450; FA, fatty acid; IL-1, interleukin-1; LCPUFA; long-chain polyunsaturated fatty acid; NF- $\mathrm{KB}$, nuclear factor- $\mathrm{B}$; NOX2, NADPH oxidase in phagocytic cells; PPAR- $\alpha$, peroxisome proliferator-activated receptor- $\alpha$; SREBP-1c, sterol regulatory element binding protein-1c; TNF- $\alpha$, tumor necrosis factor- $\alpha$. 
considering that (i) pharmacological and other liver preconditioning maneuvers have not been transferred to clinical application (Casillas-Ramírez et al., 2006); and (ii) $\mathrm{T}_{3}$ is an endobiotic substance, widely used and a well-tolerated therapeutic agent, which at low doses has either no significant adverse effects or minimal side actions than can be readily controlled. However, prevention of IR injury in humans during liver surgery and liver transplantation using reduced-size grafts from living donors await further experimental and clinical studies. Development of a progressive and severe pro-oxidant state in the liver of obese NAFLD patients is associated with the onset of steatosis and its progression to steatohepatitis as a chronic model of nutritional oxidative stress. The molecular pathogenesis of NAFLD in obese patients seems to be multifactorial, with oxidative stress and insulin resistance as major pathophysiological mechanisms that might be interdependent (Videla et al., 2006). Considering the lack of an effective drug therapy for NAFLD at present (Angulo, 2002), further studies of potentially attractive therapeutic targets are required. These might include the expression and activation status of metabolic (PPAR- $\alpha$ and SREBP-1c) and pro-inflammatory (NF- $\mathrm{B}$ and $\mathrm{AP}-1)$ transcription factors, and the activity of enzymes associated with insulin resistance such as serine/threonine stress kinases and protein tyrosine phosphatases, which will undoubtedly contribute to understanding the role of chronic and progressive oxidative stress and insulin resistance in determining steatosis and its progression to NASH. It is suggested that weight loss, as a central therapeutic issue, might be combined with antioxidants, to minimize or prevent the onset of oxidative stress-induced inflammatory response and insulin resistance, and/or $n$-3 LCPUFA, to improve the efficiency of signaling cascades related to hepatic lipid metabolism and insulin resistance (Videla, 2008).

\section{ACKNOWLEDGEMENTS}

The author is grateful to FONDECYT (grant 1090020) for financial support. Thanks are due to Drs. V. Fernández, G. Tapia, P. Varela, P. Romanque, P. Cornejo, R. Rodrigo, J. Araya, and J. Poniachik for valuable discussions. Their contributions are cited in this review.

\section{REFERENCES}

AGRAWAL A, CHA-MOLSTAD H, SAMOLS D, KUSHNER I (2003) Overexpressed nuclear factor-kappaB can participate in endogenous $\mathrm{C}$-reactive protein induction, and enhances the effects of C/EBPbeta and signal transducer and activator of transcription-3. Immunology 108: 539-547.

ANGULO P (2002) Nonalcoholic fatty liver disease. N Engl J Med 346: 1221-1231.

ARAYA J, RODRIGO R, VIDELA LA, THIELEMANN L, ORELLANA M, PETTINELLI P, PONIACHIK J (2004) Increase in long-chain polyunsaturated fatty acid $n-6 / n-3$ ratio in relation to hepatic steatosis in patients with non-alcoholic fatty liver disease. Clin Sci 106: 635-643.

ARONIS A, MADAR Z, TIROSH O (2005) Mechanism underlying oxidative stress-mediated lipotoxicity: exposure of J774.2 macrophages to triacylglycerols facilitates mitochondrial reactive oxygen species production and cellular necrosis. Free Radic Biol Med 38: $1221-1230$.

BABIOR BM (2004) NADPH Oxidase. Curr Opin Immunol 16: 42-47.
BOVERIS A, REPETTO MG, BUSTAMANTE J, BOVERIS AD, VALDEZ LB (2008) The concept of oxidative stress in pathology. In: ALVAREZ S, EVELSON P (eds) Free Radical Pathophysiology. Kerala, India: Transworld Research Network, pp:1-17.

CARO AA, CEDERBAUM AI (2004) Oxidative stress, toxicology, and pharmacology of CYP2E1. Annu Rev Pharmacol Toxicol 44: 27-42.

CASILLAS-RAMÍREZ A, MOSBAH IB, RAMALHO F, ROSELLÓCATAFAU J, PERALTA C (2006) Past and future approaches to ischemia-reperfusion lesion associated with liver transplantation. Life Sci 79: 1881-1894.

CLARKE SD (2004) The multi-dimensional regulation of gene expression by fatty acids: polyunsaturated fats as nutrient sensors. Curr Opin Lipidol 15: 13-18.

DRÖGE W (2002) Free radicals in the physiological control of cell function. Physiol Rev 82: 47-95.

ELIZONDO A, ARAYA J, RODRIGO R, SIGNORINI C, SGHERRI C, COMPORTI M, PONIACHIK J, VIDELA LA (2008) Effects of weight loss on liver and erythrocyte polyunsaturated fatty acid pattern and oxidative stress status in obese patients with non-alcoholic fatty liver disease. Biol Res 41: 59-68.

EVANS JL, MADDUX BA, GOLDFINE ID (2005) The molecular basis for oxidative stress-induced insulin resistance. Antioxid Redox Signal 7: 1040-1052.

FAUSTO N, CAMPBELL JS, RIEHLE KJ (2006) Liver regeneration. Hepatology 43: S45-S53.

FERNÁNDEZ V, BARRIENTOS $\mathrm{X}$, KIPREOS $\mathrm{K}$, VALENZUELA A, VIDELA LA (1985) Superoxide radical generation, NADPH oxidase activity, and cytochrome P450 content in an experimental hyperthyroid state: relation to lipid peroxidation. Endocrinology 117: 496-501.

FERNÁNDEZ V, VIDELA LA (1993) Influence of hyperthyroidism on superoxide radical and hydrogen peroxide production by rat liver submitochondrial particles. Free Radic Res Commun 18: 329-335.

FERNÁNDEZ V, VIDELA LA (1996) Biochemical aspects of cellular antioxidant systems. Biol Res 29: 177-182.

FERNÁNDEZ V, VIDELA LA, TAPÌA G, ISRAEL Y (2002) Increases in tumor necrosis factor-a in response to thyroid hormone-induced liver oxidative stress in the rat. Free Radic Res 36: 719-725.

FERNÁNDEZ V, MASSA L, QUIÑONES L, SIMON-GIAVAROTTI KA GIAVAROTTI L, D'ALMEIDA V, AZZALIS LA, JUNQUEIRA VBC, VIDELA LA (2003) Effects of $\gamma$-hexachlorocyclohexane and L-3,3,5triiodothyronine on rat liver cytochrome P4502E1-dependent activity and content in relation to microsomal superoxide radical generation. Biol Res 36: 359-365.

FERNÁNDEZ V, TAPIA G, VARELA P, VIDELA LA (2005a) Redox regulation of thyroid hormone-induced Kupffer cell-dependent IкB- $\alpha$ phosphorylation in relation to inducible nitric oxide synthase expression. Free Radic Res 39: 411-418.

FERNÁNDEZ V, TAPIA G, VARELA P, CASTILLO I, MORA C, MOYA F, ORELLANA M, VIDELA LA (2005b) Redox-up-regulated expression of rat liver manganese superoxide dismutase and $\mathrm{Bcl}-2$ by thyroid hormone is associated with inhibitor of $\kappa \mathrm{B}-\alpha$ phosphorylation and nuclear factor- $\kappa \mathrm{B}$ activation. J Endocrinol 186: 539-547.

FERNÁNDEZ V, REYES S, BRAVO S, SEPÚLVEDA R, ROMANQUE P, SANTANDER G, CASTILLO I, VARELA P, TAPIA G, VIDELA LA (2007a) Involvement of Kupffer cell-dependent signaling in $\mathrm{T}_{3}$ induced hepatocyte proliferation in vivo. Biol Chem 388: 831-837.

FERNÁNDEZ V, CASTILLO I, TAPIA G, ROMANQUE P, URIBEECHEVARRÍA S, URIBE M, CARTIER-UGARTE D, SANTANDER G, VIAL MT, VIDELA LA (2007b) Thyroid hormone preconditioning: protection against ischemia-reperfusion liver injury in the rat. Hepatology 45: 170-177

FERNÁNDEZ V, TAPIA G, VARELA P, GAETE L, VERA G, MORA C, VIAL MT, VIDELA LA (2008) Causal role of oxidative stress in liver preconditioning by thyroid hormone in rats. Free Radic Biol Med 44: 1724-1731.

FERNÁNDEZ V, VIDELA LA (2009) Kupffer cell-dependent signaling in thyroid hormone calorigenesis: possible applications for liver preconditioning. Curr Signal Trans Ther 4:144-151.

GLOIRE G, LEGRAND-POELS S, PIETTE J (2006) NF- $\kappa$ B activation by reactive oxygen species: fifteen years later. Biochem Pharmacol 72: 1493-1505.

GOMES LF, LORENTE S, SIMON-GIAVAROTTI KA, ARECO KN, ARAUJO-PERES C, VIDELA LA (2004) Tri-iodothyronine differentially induces Kupffer cell ED1/ED2 subpopulations. Mol Aspects Med 2004; 25: 183-190. 
HIRANO T, ISHIHARA K, HIBI M (2000) Roles of STAT3 in mediating the cell growth, differentiation and survival signals relayed through the IL-6 family of cytokine receptors. Oncogene 19: 2548-2556.

HOUSTIS N, ROSEN ED, LANDER ES (2006) Reactive oxygen species have a causal role in multiple forms of insulin resistance. Nature 440; 944-948.

HUH K, KWON TH, KIM JS, PARK JM (1998) Role of the hepatic xanthine oxidase in thyroid dysfunction: effect of thyroid hormones in oxidative stress in rat liver. Arch Pharmac Res 21: 236-240.

KOBAYASHI M, YAMAMOTO M (2005) Molecular mechanisms activating the Nrf2-Keap1 pathway of antioxidant gene regulation. Antioxid Redox Signal 7: 385-394.

MALAGUARNERA L, DI ROSA M, ZAMBITO AM, DELLOMBRA N, NICOLRTTI F, MALAGUARNERA M (2006) Chitotriosidase gene expression in Kupffer cells from patients with non-alcoholic fatty liver disease. Gut 55: 1313-1320.

ORELLANA M, RODRIGO R, VARELA N, ARAYA J, PONIACHIK J, CSENDES A, SMOK G, VIDELA LA (2006) Relationship between in vivo chlorzoxazone hydroxylation, hepatic cytochrome P450 2E1 content and liver injury in obese non-alcoholic fatty liver disease patients. Hepatol Res 34: 57-63.

POLI G, LEONARDUZZI G, BIASI F, CHIARPOTTO E (2004) Oxidative stress and cell signaling. Curr Med Chem 11: 1163-1182.

RAM PA, WAXMAN DJ (1992) Thyroid hormone stimulation of NADPH P450 reductase expression in liver and extrahepatic tissues. J Biol Chem 267: 3294-3301.

RAMADORI G, CHRIST B (1999) Cytokines and the hepatic acute-phase response. Sem Liver Dis 19: 141-155.

ROMANQUE P, URIBE M, VIDELA LA (2005) Mecanismos moleculares en el daño por isquemia-reperfusión y en el preacondicionamiento isquémico. Rev Méd Chile 133: 469-476.

SCHWARTZ HL, OPPENHEIMER JH (1978) Physiologic and biochemical actions of thyroid hormone. Pharmacol Ther Part B 3: 349-376.

SEKI S, KITADA T, YAMADA T, SAKAGUCHI H, NAKATANI K, WAKASA K (2002) In situ detection of lipid peroxidation and oxidative DNA damage in non-alcoholic fatty liver diseases. J Hepatol 37: 56-62.

SIES H (1986) Biochemistry of oxidative stress. Angew Chem Int Ed Engl 25: 1058-1071.

TAPIA G, PEPPER I, SMOK G, VIDELA LA (1997) Kupffer cell function in thyroid hormone-induced liver oxidative stress in the rat. Free Radic Res 26: 267-279.
TAPIA G, FERNÁNDEZ V, VARELA P, CORNEJO P, GUERRERO J, VIDELA LA (2003) Thyroid hormone-induced oxidative stress triggers nuclear factor- $\mathrm{\kappa B}$ activation and cytokine gene expression in rat liver. Free Radic Biol Med 35: 257-265.

TAPIA G, FERNÁNDEZ V, PINO C, ARDILES R, VIDELA LA (2006) The acute-phase response of the liver in relation to thyroid hormoneinduced redox signaling. Free Radic Biol Med 40: 1628-1635.

TSUKAMOTO H (2002) Redox regulation of cytokine expression in Kupffer cells. Antiox Redox Signal 4: 741-748.

VARELA P, TAPIA G, FERNÁNDEZ V, VIDELA LA (2006) The role of thyroid hormone calorigenesis in the redox regulation of gene expression. Biol Res 39: 611-617.

VENDITTI P, DI MEO S (2006) Thyroid hormone-induced oxidative stress. Cell Mol Life Sci 63: 414-434.

VIDELA LA, FERNÁNDEZ V (1988) Biochemical aspects of cellular oxidative stress. Arch Biol Med Exp 21: 85-92.

VIDELA LA, RODRIGO R, ARAYA J, PONIACHIK J (2004a) Oxidative stress and depletion of long-chain polyunsaturated fatty acids may contribute to nonalcoholic fatty liver disease. Free Radic Biol Med 37: 1499-1507.

VIDELA LA, RODRIGO R, ORELLANA M, FERNÁNDEZ V, TAPIA G, QUIÑONES L, VARELA N, CONTRERAS J, LAZARTE R, CSENDES A, ROJAS J, MALUENDA F, BURDILES P, DÍAZ JC, SMOK G, THIELEMANN L, PONIACHIK J (2004b) Oxidative stress-related parameters in the liver of non-alcoholic fatty liver disease patients. Clin Sci 106: 261-268.

VIDELA LA, RODRIGO R, ARAYA J, PONIACHIK J (2006) Insulin resistance and oxidative stress interdependency in non-alcoholic fatty liver disease. Trends Mol Med 12: 555-558.

VIDELA LA, FERNÁNDEZ V, TAPIA G, VARELA P (2007) Thyroid hormone calorigenesis and mitochondrial redox signaling: upregulation of gene expression. Front Biosc 12: 1220-1228.

VIDELA LA (2008) Oxidative stress and insulin resistance as interdependent pathogenic mechanisms in non-alcoholic fatty liver disease associated with obesity. In: ALVAREZ S, EVELSON P (eds) Free Radical Pathophysiology. Kerala, India: Transworld Research Network, pp:369-385.

VIDELA LA, TAPIA G, RODRIGO R, PETTINELLI P, HAIM D, SANTIBAÑEZ C, ARAYA AV, SMOK G, CSENDES A, GUTIERREZ L, ROJAS J, CASTILLO J, KORN O, MALUENDA F, DÍAZ JC, RENCORET G, PONIACHIK J (2009) Liver NF-אB and AP-1 DNA binding in obese patients. Obesity 17: 973-979. 
